\title{
Upstream dam impacts on gilded catfish Brachyplatystoma rousseauxii (Siluriformes: Pimelodidae) in the Bolivian Amazon
}

\author{
Paul A. Van Damme ${ }^{1,2}$, Leslie Córdova-Clavijo ${ }^{1}$, Claudio Baigún ${ }^{3}$, Marilia Hauser ${ }^{4,5}$, \\ Carolina R. da Costa Doria ${ }^{4,5}$ and Fabrice Duponchelle ${ }^{5,6}$
}

This paper explores the effects of two run-of-river dams (Jirau and Santo Antônio) built in cascade in the middle Madeira River (Brazil) on the interruption of long-distance migration routes of the gilded catfish (Brachyplatystoma rousseauxii). A participative monitoring system was set up to compare capture by commercial fishers approximately $1500 \mathrm{~km}$ upstream of the dams in Bolivia, before (1998-2007) and after (2015-2017) dam closure. A significant decrease in gilded catfish catches and in catch per unit effort was observed after dam closure, whereas no significant difference in mean weight was found. Back-estimation of age suggests that the few individuals remaining after dam closure in 2009 are a mixture of old homers that returned upstream before dam closure, and residents hatched after dam closure and trapped in the upper Madeira. Unless fishways in the Madeira River dams improve their efficiency, the gilded catfish might become rare and in danger of regional extinction in the upper Madeira basin in the next few years, negatively affecting river fisheries.

Keywords: Environmental impact, Fish migration, Fishways, Madeira dams, River connectivity.

Este estudio explora el impacto de las represas en cascada Jirau y Santo Antônio en el curso medio del río Madeira (Brasil) sobre la interrupción de la ruta de migración del bagre dorado (Brachyplatystoma rousseauxii). Se estableció un sistema de monitoreo participativo para comparar la captura de dorado por pescadores comerciales en Bolivia, aproximadamente $1500 \mathrm{~km}$ río arriba de las represas, antes (1998-2007) y después (2015-2017) de su cierre. Se observó una disminución significativa en las capturas y en la captura por unidad de esfuerzo de dorado después del cierre de ambas represas. No hubo diferencias significativas en el peso promedio antes y después del cierre. La estimación de la edad de los pocos individuos capturados arriba de las represas sugiere que se trata de una mezcla de individuos adultos que han podido pasar las represas antes de su cierre en 2009, y residentes nacidos después del cierre de las represas, atrapados en el alto Madeira. Si los sistemas de traspaso de peces implementados en las represas del rio Madeira no mejoran su eficiencia, el dorado podría volverse escaso y en peligro de extinción regional en la cuenca alta del Madeira en los próximos años, afectando negativamente la pesca de esta especie.

Palabras clave: Conectividad de ríos, Impacto ambiental, Migración de peces, Represas del río Madeira, Sistemas de traspaso de peces.

\section{Introduction}

Dams are considered one of the main pressures leading to aquatic habitat degradation in the Amazon river basin (Winemiller et al., 2016; Castello, Macedo, 2016; Lees et al., 2016; Forsberg et al., 2017; Latrubesse et al.,
2017; Timpe, Kaplan, 2017). The planned construction of hydroelectric dams along the Andes-to-Amazon gradient and the creation of reservoirs will increasingly interrupt free water and sediment flow (Anderson et al., 2018). One of the most cited impacts of these dams is on long-distance migratory fish species, the completion of their life cycle

${ }^{1}$ FAUNAGUA, Instituto de Investigación Aplicada de Recursos Acuáticos, Final Av. Max Fernández, Sacaba, Cochabamba, Bolivia. (LCC) leslie.cordova@gmail.com, Dhttps://orcid.org/0000-0002-5346-0364

${ }^{2}$ Unidad de Limnología y Recursos Acuáticos (ULRA), Universidad Mayor de San Simón, Parque La Torre, Cochabamba, Bolivia. (PAVD) paul.vandamme@faunagua.org (corresponding author), Dhttps://orcid.org/0000-0002-9960-1978

${ }^{3}$ Instituto de Investigación e Ingeniería Ambiental, (CONICET-UNSAM), Argentina. cbaigun@gmail.com, Dhttps://orcid.org/00000001-8412-8586

${ }^{4}$ Laboratoire Mixte International - Evolution et Domestication de 1'Ichtyofaune Amazonienne (LMI - EDIA), IIAP - UAGRM - IRD, France. (MH) mariliahauser@gmail.com, Dhttps://orcid.org/ 0000-0002-9013-0970

${ }^{5}$ Laboratório de Ictiologia e Pesca, Departamento de Ciências Biológicas, Universidade Federal de Rondônia (UNIR), Porto Velho, RO, Brazil. (CRCD) carolinarcdoria@unir.br, Dhttps://orcid.org/0000-0003-1638-0063

${ }^{6}$ Institut de Recherche pour le Développement (IRD), UMR MARBEC (Univ. Montpellier, CNRS, IFREMER, IRD), Montpellier, France. (FD) fabrice.duponchelle@ird.fr, Dhttps://orcid.org/0000-0003-0497-2264 
depending on river connectivity (Anderson et al., 2018), preservation of the hydrological cycle (Lima et al., 2017) and the availability of suitable upstream spawning habitats (Barthem et al., 2017). These impacts on migratory fish are difficult to mitigate, although there is past and ongoing research and experimentation on fishways performance (Godinho, Kynard, 2009; Baigún et al., 2012). Given the low efficiency of these systems for Neotropical species (Oldani et al., 2007; Baigún et al., 2007; Pompeu et al., 2012; Lira et al., 2017), in some cases aquaculture has been proposed as mitigation strategy, even though this activity may affect fisheries resources indirectly (see, for example, Pelicice et al., 2014; Montanhini Neto et al., 2015).

Two run-of-river dams (Jirau, Santo Antônio) have been constructed in cascade in the middle Madeira River, in Brazil, downstream of the Bolivian-Brazilian border. The impacts of this type of dams on the aquatic environment is due to changes in hydrological and sediment regimes, and position along fish migration routes (Fearnside, 2014; Santos et al., 2018), affecting especially migratory catfish (Duponchelle et al., 2016; Hauser, 2018; Hauser et al., 2018; Hauser et al., 2019) and fisheries (Lima et al., 2017; Santos et al., 2018). The latter authors reported a 74\% reduction in fish landings downstream of the Madeira dams during construction and after closure (2009-2014).

The gilded catfish Brachyplatystoma rousseauxii (Castelnau, 1855) is the species most affected by these dams. This catfish undertakes the longest migrations known in freshwater habitats (Barthem, Goulding, 1997; Coronel et al., 2004; Duponchelle et al., 2016; Barthem et al., 2017; Hauser, 2018) and spawns in Bolivia mainly in the upper Beni and Mamoré rivers, which are Amazonian headwaters close to the lower Andean foothills (Van Damme et al., 2011; Barthem et al., 2017). Larvae and juveniles drift downstream more than $4000 \mathrm{~km}$ and reach the Amazon estuary, where they feed during approximately two years, after which they disperse upstream across the basin, and undertake upstream migration to their spawning habitats (Barthem, Goulding, 1997; Barthem et al., 2017). Duponchelle et al. (2016) and Hauser (2018), based on population studies and strontium isotope analysis of otoliths, provided evidence that for most individuals in the Madeira basin natal homing is the normal behavior to complete their life cycle, although a low percentage of the individuals encountered in the Bolivian Amazon were natural residents with unknown reproduction pattern. Most gilded catfish that migrated upstream and passed the waterfalls in the Bolivia-Brazil border area in the pre-dam period (now partly flooded by dams) stayed in the upper Madeira (Bolivian and Peruvian territory) afterwards and never returned to the lower Madeira or Amazon (Duponchelle et al., 2016; Hauser, 2018). Annual spawning of these individuals in the headwaters is suggested by the presence of ripe individuals between February and April (Coronel et al., 2004) and by the increased abundance of downstream drifting larvae and juveniles in the dry season in survey sites close to the dams (Cella-Ribeiro et al., 2015).
Duponchelle et al. (2016) and Hauser (2018) showed that the typical homing behavior of gilded catfish is now interrupted due to the Jirau and Santo Antônio dams restricting passage of upstream migrating pre-adult gilded catfish. However, the potential impacts of these dams in the upper Madeira basin in Bolivian territory have not yet been assessed (MRE-MMAyA, 2014). Appraisal of these impacts on migratory fish in the upper Madeira was so far hampered by the fact that Environmental Impact Studies or Assessments were limited to the area in Brazilian territory immediately adjacent to the dams, with effects upstream of the Brazilian-Bolivian border being underestimated.

The objective of this study was to assess the impact of the closure of the Jirau and Santo Antônio dams on the gilded catfish population in the upper Madeira River basin, using fishery landing data. We first assessed whether there existed a negative population trend in the pre-dam period caused by either natural or anthropogenic factors other than dams, and which eventually might explain population decrease in the post-dam period. We then investigated the hypothesis that dams affected gilded catfish by comparing pre-dam and post-dam catch, catch per unit effort (CPUE), fish weight and age. The probability of dam-induced regional extinction of the species was discussed interpreting both published literature and observed changes in fish landings.

\section{Material and Methods}

Study area. The study was conducted in the Ichilo River, an Amazon headwater of the Mamoré River, tributary of the Madeira River. The main landing site in the study area is Puerto Villarroel, a small town of 3000 habitants in Bolivia, where navigation, commercial fishing and tourism are the main activities providing family income and employment (Van Damme et al., 2011) (Fig. 1).

The river originates upstream of the Carrasco and Amboró National Parks (Bolivia) at an altitude of $4500 \mathrm{~m}$ above sea level. The climate is humid to hyperhumid, with annual rainfall of $2497 \mathrm{~mm}$ and mean annual temperature of $23.6^{\circ} \mathrm{C}$ (Navarro, Maldonado, 2002). The river stretch used by commercial fishers has a length of approximately 300 $\mathrm{km}$ and an altitude between 160 and $190 \mathrm{~m}$ above sea level. Fisheries resources are exploited in the main river channel, in small tributaries and in oxbow lakes. The river exhibits two well defined hydrological peaks characterized by highest water levels in summer (February - March) and lowest water levels at the end of the winter (August - September).

Santo Antônio and Jirau dams, located in the Madeira River (Brazil), were constructed in different stages between 2008 and 2016 (Santos et al., 2018). The construction of the Santo Antônio dam $\left(08^{\circ} 48^{\prime} \mathrm{S} 63^{\circ} 56^{\prime} \mathrm{W}\right)$, situated $1768 \mathrm{~km}$ downstream of Puerto Villarroel and $100 \mathrm{~km}$ downstream of Jirau dam (Fig. 1), started in September 2008. Reservoir filling started in September 2011, when the first of the sluice gates was closed. The first turbines began to operate on March 30th 2012, and all 50 turbines were operational in 
November 2016. This dam possesses a fishway composed of an artificial channel foreseen with a river-type substrate and simulating the original Madeira River flows in the rapids (Fearnside, 2014). Jirau dam construction started in June 2009 , the river was dammed to fill the reservoir in October 2012, the first turbine began operating in September 2013 and the construction was completed in December 2016 with 50 turbines. The fishways of this dam consist of two artificial channels equipped with a fish attraction system and a tank, where the fish are trapped, manually selected and subsequently transferred upstream by a truck.

Methods. A participative monitoring system of catches was set up with fishers of Puerto Villarroel, with data collected from an average annual number of $9.9( \pm 3.9$; range 4-17) commercial fishery boats participating between 1998 and 2007 (10 years pre-dam period) and 8.7 boats $( \pm 2.5$; range 6-11) between 2015 and 2017 (three years post-dam period). This number of boats is equivalent to approximately $80 \%$ of the total fishery fleet in Puerto Villarroel (Van Damme et al., 2011). Data for the period 2008-2014 were not available. Overall, captured fish were monitored daily on board during 768 fishing trips over the 13-year monitoring period, 666 before and 102 after dam closure. A form filled by trained fishers during each trip provided daily catch data by species, individual fish weight, as well as information on fishing gear, fishing location and crew members. Such form generally covered fishing trips of between 4 and 20 days with a crew of two to four fishers.
Gilded catfish is captured in the Ichilo River channel, where it forms part of a multi-species catfish fisheries (Doria et al., 2018a). We calculated river catch as the sum of catfish species caught in rivers using five fishing methods: hooks fixed to drifting boys (locally denominated as "bidónes"), fixed hooks on lines ("espineles)", longlines, drifting gill nets with large mesh size and enclosure nets used in shallow waters along the shore line. Catch using drifting nets with small mesh size, used in the capture of Prochilodus nigricans, and the catch of the scavenger species Calophysus macropterus using bait immersed in submerged cages were excluded from the analysis. Driftnets also occasionally capture a large frugivorous characid belonging to the order Characiformes, Colossoma macropomum (named "pacú" in Bolivia).

Individual gilded catfish weights estimated by fishers were obtained from 459 individuals, 445 before and 14 after dam closure. Fishers were trained in estimating individual weights at the beginning of each sampling period, in 1998 and 2015 respectively, by using a scale with a capacity of $50 \mathrm{~kg}$, and thereafter all weights of captured catfish were estimated visually by the fishers. Only $72 \%$ of the individual weights were included in the analysis because fishers grouped the weights of some individuals. No distinction was made between males and females. Specimens were deposited in the collection of the Unidad de Limnologia y Recursos Acuáticos (Universidad Mayor de San Simon) in the Museo de Historia Natural Alcides d'Orbigny, Cochabamba, Bolivia (catalogue number UMSS 07208).

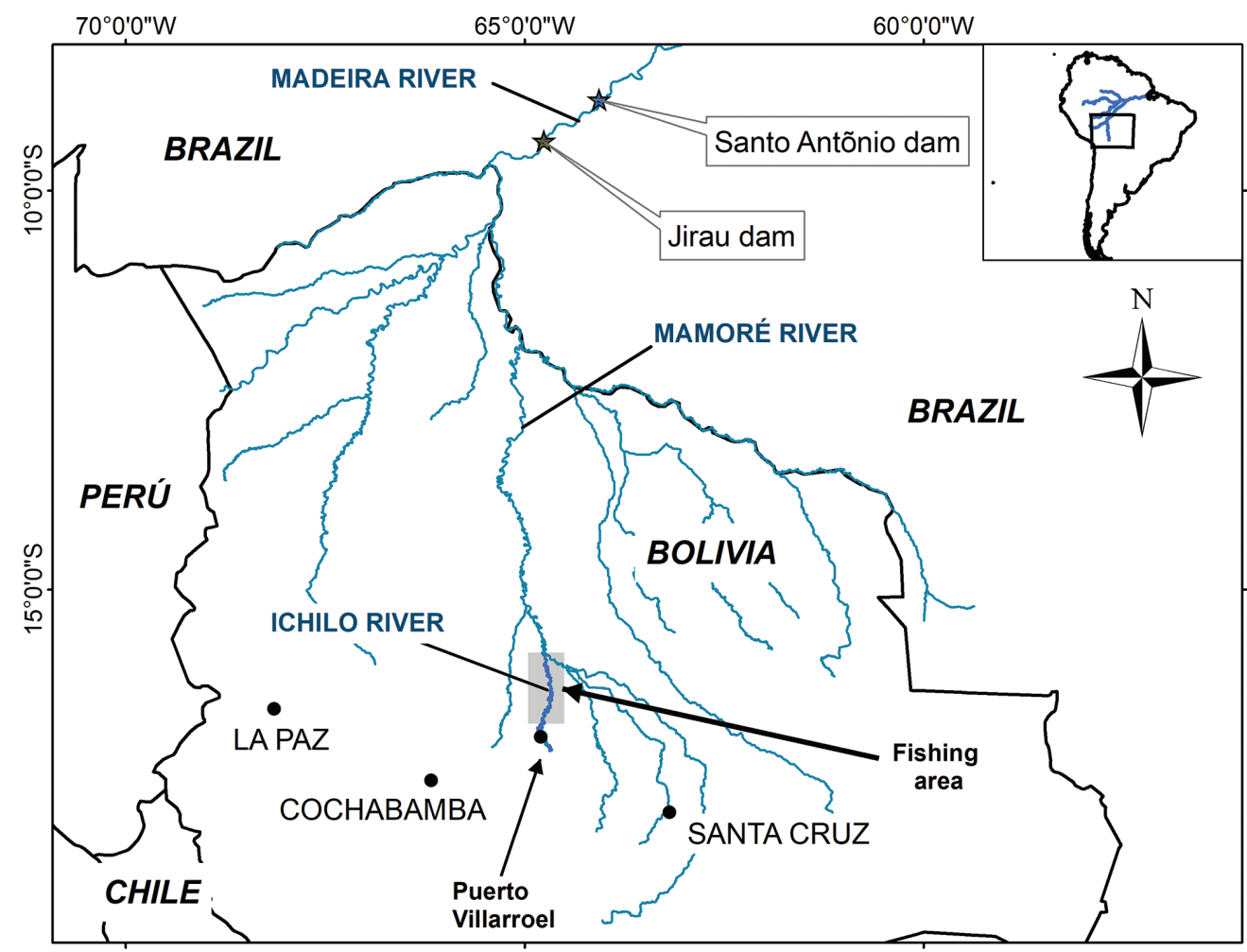

Fig. 1. Upper Madeira River basin, showing landing site Puerto Villarroel and fishing area in the Ichilo River (Bolivian Amazon), as well as the Santo Antônio and Jirau dams (Brazilian Amazon). 
Data Analysis. We calculated the monthly and annual contribution of gilded catfish to total river catch before and after dam closure. Catch per unit effort (CPUE) was calculated as the gilded catfish catch (in $\mathrm{kg}$ ) by one fisher per day. Trends in gilded catfish CPUE between 1998 and 2007 were tested by linear regression analysis to evaluate whether there might have been a downward trend before dam closure, which eventually might explain the observed low CPUE after dam closure. Differences in percentage contribution of $B$. rousseauxii to catch and differences in CPUE before and after dam closure were tested by a nonparametric test (Kruskal-Wallis one-way ANOVA on ranks).

Kruskal-Wallis test was also used to evaluate weight differences between individuals before and after dam closure. Length and age range of the individuals caught by fishers before and after dam closure was back-estimated from weights using the standard length (SL) - weight (W) relationship $\mathrm{W}=0.02 \mathrm{SL}^{2.936}\left(\mathrm{r}^{2}=0.894\right)$ and the von Bertalanffy growth equation $\mathrm{SL}_{\mathrm{t}}=102.84\left(1-\mathrm{e}^{-0.57(\mathrm{t}}\right.$ ${ }^{-0.021)}$ ), with $\mathrm{t}=$ age (in years) (from Hauser et al., 2018). Age variation for each weight class was used to explore the possible life cycle of individuals registered in the predam and post-dam period. Based on Hauser et al. (2018), individuals captured in the upper Madeira basin weighing between $7-8 \mathrm{~kg}$ have an age between 2.5 and 5 years old, individuals of $9 \mathrm{~kg}$ have any age between 3 and 7 years old, whereas individuals $>9 \mathrm{~kg}$ could have any age between 3 and 15 years.

\section{Results}

Catches in the Ichilo River were characterized by longand medium-distance migratory species. The nine larger catfish species (family Pimelodidae) caught were typical riverine species exhibiting various types of longitudinal and lateral migratory behavior (Tab. 1).

Total river catch registered in the pre-dam period was 243 tons, with an average of $24( \pm 9)$ tons/year $(\mathrm{N}=10$ years), whereas in the post-dam period the total was 49 tons $(\mathrm{N}=3$ years), with an average of $16( \pm 5)$ tons/year. The contribution of gilded catfish to total river catch decreased after river damming. Before dam closure, the species accounted for $5.5( \pm 2.5) \%$ (range $1.8-10.3 \%$ ) of river catch, whereas it only accounted for $0.4 \%( \pm 0.1)$ (range $0.3-0.5 \%)$ after dam closure (Fig. 2). Before closure, annual CPUE of gilded catfish fluctuated between 0.34 and $1.56 \mathrm{~kg} /$ fisher*day, with a mean of $0.78( \pm 0.39)$ (Fig. 2). There was no significant negative trend in the slope of the linear regression of catch per unit effort against time $(\mathrm{b}=-0.025 ; \mathrm{F}=0.326, \mathrm{p}>0.05)$ before dam closure. Annual CPUE levels of gilded catfish in the post-dam period were below $0.13 \mathrm{~kg} /$ fisher*day, which was a significant decrease in comparison with the pre-dam period (Kruskal Wallis, $\mathrm{H}=6.43 ; \mathrm{p}=0.01$ ).

Gilded catfish showed a very distinctive seasonal pattern in the study area, with mature individuals appearing in the catch in October or November, when water levels start to rise, and reaching a peak during the receding water period from March to May (Fig. 3). Before dam closure, 70.4\% of all gilded catfish were caught in March and April. In these months, average CPUEs were of 3.4 and $1.6 \mathrm{~kg} /$ fisher*day. The species almost disappeared from the catch during the low water period, notwithstanding the continued effort using catfish-specific fishing methods, to appear again at the beginning of the raining season in NovemberDecember when water level started increasing again. The low catch between December and February coincided with the observed low fishing effort during prohibition of commercial fishing by the government regulations. After dam closure, although catfish-specific effort throughout the receding and low water periods remained high, there was a significant drop in monthly CPUE, below $0.02 \mathrm{~kg} /$ fisher*day throughout the year (Fig 3).

The mean weight of the 445 individuals caught before dam closure was $9.4(+/-3.0) \mathrm{kg}$, ranging between 4 and 17 $\mathrm{kg}$, whereas the mean weight of the 14 individuals caught after dam closure was $13.0(+/-3.7) \mathrm{kg}$, all weighing $7 \mathrm{~kg}$ or more (Fig. 4). Nevertheless, there was no significant difference in mean weight before and after dam closure (Kruskal Wallis; $\mathrm{H}=3.19$; $\mathrm{p}=0.07$ ). Of the 14 individuals captured after dam closure, one individual captured in 2016 and two individuals in 2017 weighed respectively 8 and $7 \mathrm{~kg}$.

Tab. 1. Fish species caught in the Ichilo River recorded by fishers of Puerto Villarroel. Within each order species are listed in alphabetic order. M1=Long-distance longitudinal migration; $\mathrm{M} 2=$ =ntermediate distance longitudinal migration, $\mathrm{ML}=$ Intermediate distance longitudinal and lateral migration (following Barthem, Goulding, 2007).

\begin{tabular}{|c|c|c|}
\hline Species name & Local names & Migratory habits \\
\hline \multicolumn{3}{|l|}{ Order SILURIFORMES } \\
\hline $\begin{array}{l}\text { Brachyplatystoma filamentosum } \\
\text { (Lichtenstein, 1819) }\end{array}$ & Bacalao & M2 \\
\hline $\begin{array}{l}\text { Brachyplatystoma rousseauxii } \\
\text { (Castelnau, 1855) }\end{array}$ & Dorado, plateado & M1 \\
\hline $\begin{array}{l}\text { Brachyplatystoma platynemum } \\
\text { Boulenger, } 1898\end{array}$ & Barbachata & M1 \\
\hline $\begin{array}{l}\text { Phractocephalus hemioliopterus } \\
\text { (Bloch \& Schneider, 1801) }\end{array}$ & General & ML \\
\hline $\begin{array}{l}\text { Pseudoplatystoma fasciatum } \\
\text { (Linnaeus, 1766) }\end{array}$ & Surubí & ML \\
\hline $\begin{array}{l}\text { Pseudoplatystoma tigrinum } \\
\text { (Valenciennes, 1840) }\end{array}$ & Chuncuina & ML \\
\hline $\begin{array}{l}\text { Oxydoras niger } \\
\text { (Valenciennes, 1821) }\end{array}$ & Boni & M2 \\
\hline $\begin{array}{l}\text { Sorubimichthys planiceps } \\
\text { (Spix \& Agassiz, 1829) }\end{array}$ & Paleta & M2 \\
\hline $\begin{array}{l}\text { Zungaro zungaro } \\
\text { (Humboldt, 1821) }\end{array}$ & Muturo & M2 \\
\hline \multicolumn{3}{|l|}{ Order CHARACIFORMES } \\
\hline $\begin{array}{l}\text { Colossoma macropomum } \\
\text { (Cuvier, 1816) }\end{array}$ & Pacú & ML \\
\hline
\end{tabular}




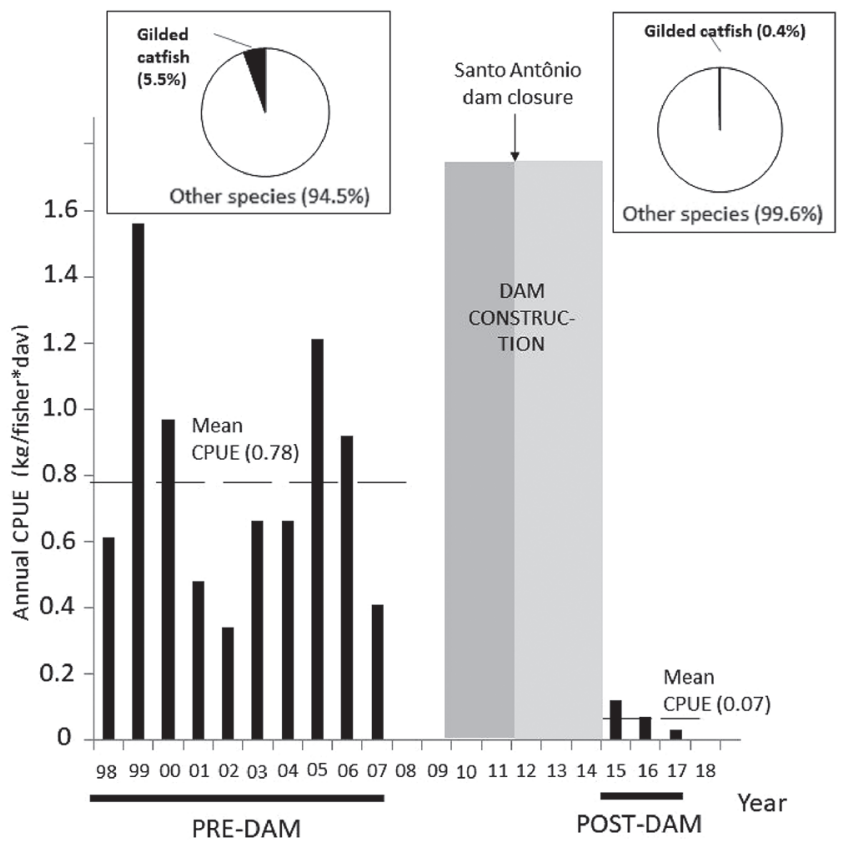

Fig. 2. Annual catch per unit effort (CPUE) of Brachyplatystoma rousseauxii before and after dam closure. The horizontal dotted line before dam closure depicts the mean annual CPUE between 1998 and 2007. The inserted diagrams show the relative contribution of gilded catfish to river catch before and after closure.

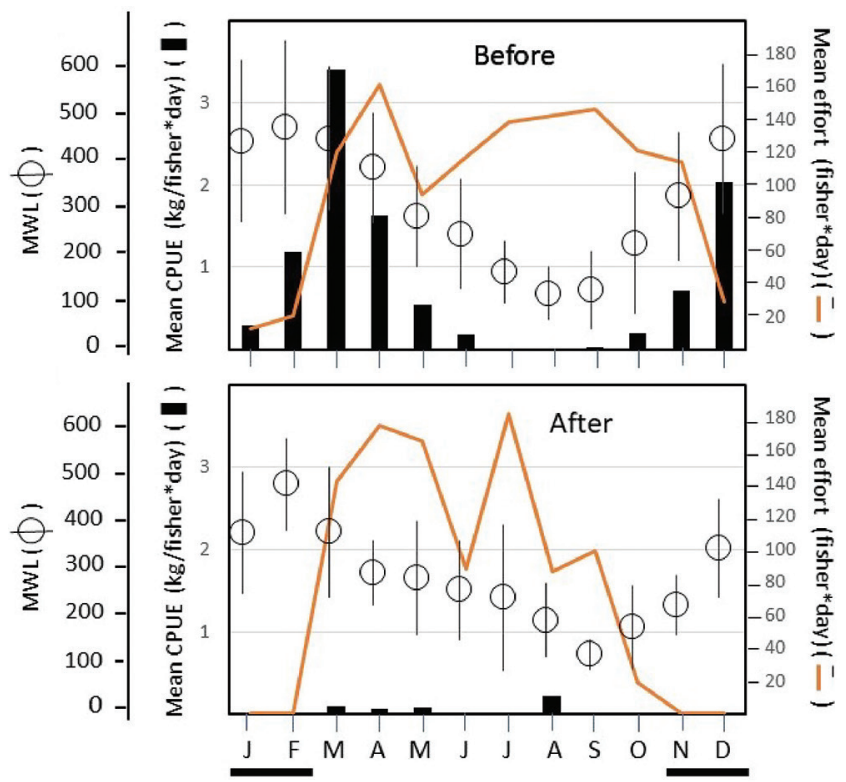

Fig. 3. Mean annual fishing effort and capture per unit effort (CPUE) of Brachyplatystoma rousseauxii (black bars) per month in the Ichilo River before (1998-2007) and after dam closure (2015-2017) using catfish-specific fishing methods. Mean monthly water level (MWL) in Puerto Villarroel for the two sample periods is shown (SENAMHI 2018), with vertical lines representing standard deviation. The horizontal bars show the period when commercial fishing is prohibited.
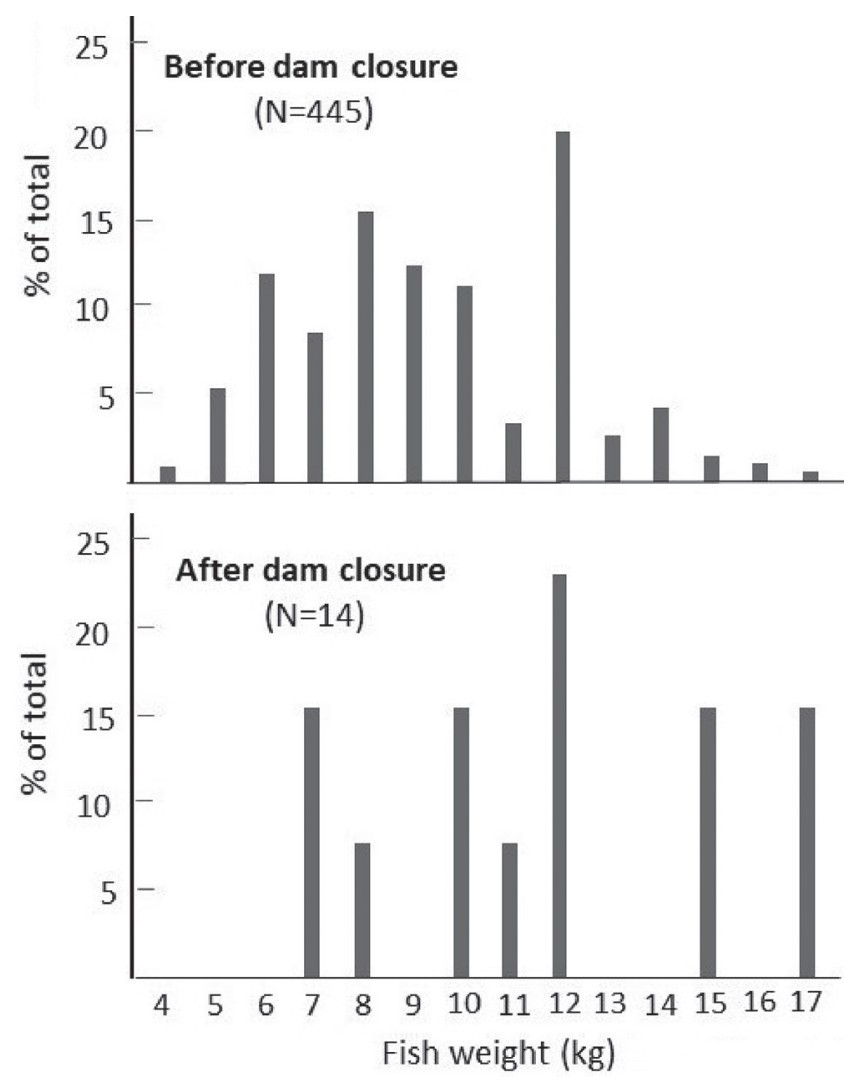

Fig. 4. Fish weight frequency distribution of Brachyplatystoma rousseauxii before and after dam closure.

Back-estimation of age indicated that $42 \%$ of the individuals captured before dam closure weighted $<9 \mathrm{~kg}$ and were thus 5 years or younger, and the remainder $58 \%$ were individuals weighing $9 \mathrm{~kg}$ or more, with ages between 3 and 15 years. After dam closure the three smallest individuals (7-8 $\mathrm{kg}$ ), which could be between 2.5 and 5 years old, represented $21 \%$ of all individuals captured, and the remaining ones with weights $>9 \mathrm{~kg}$, which could have been anything between 3 and 15 years old, represented the remaining $79 \%$.

\section{Discussion}

Commercial fisheries have been put forward in the past as one of the possible causes of gilded catfish population decline in the Amazon basin. However, although the species is intensively exploited along its upstream migration route in the Madeira and Lower Amazon rivers (Barthem, Fabré, 2004; Barthem, Goulding, 2007; Batista et al., 2012; Cruz et al., 2017), no significant decrease in capture per unit effort was observed in the middle Madeira River in the decade before start of dam construction (Lima et al., 2017; Doria et al., 2018b). The present study equally showed no negative population trend before dam construction at sites upstream from the dams in the upper Madeira River basin. This suggests that the dams represent the main cause of post-dam gilded catfish population decline, the same as was reported by Lima et al. (2020) in the middle Madeira River. 
The gilded catfish has a low natural abundance in the study area and occurs seasonally during the breeding season (Van Damme et al., 2011), making it difficult to detect longterm population trends. Notwithstanding its overall rarity and seasonal occurrence, the species was captured annually in the Ichilo River during 10 consecutive years between 1998 and 2007 before dam closure, and these data provided a reliable base line for post-dam impact evaluation. Detection of gilded catfish population trends by means of CPUE in the present study, however, was-hampered by differences in sampling efficiency before and after river damming. Particularly during high water conditions from November to February, the capture by commercial fishers could not be adequately monitored with the present methodology due to the annual fisheries ban promulgated yearly by the regional government, and corresponding drop in fishery effort. This ban was imposed more efficiently after dam closure, affecting the possibility to obtain comparable CPUE data especially during increasing and high-water levels. A reliable comparison could only be made for the months of receding waters (March-June).

Notwithstanding these limitations, the upstream monitoring of fish catches provides evidence that the Jirau and Santo Antônio dams have interrupted the former dominant migratory pattern of the gilded catfish, which involved a compulsory prolonged stay of immature fish in the estuary area (Duponchelle et al., 2016). Both dams are provided with types of fishways, of which the fish passing efficiency has been questioned in repeated occasions (Agostinho et al., 2008; Lira et al., 2017), and it is now generally assumed that they will not allow for the successful upstream migration of pre-adult goliath catfishes (Fearnside, 2014; Hahn et al., 2017; Cella-Ribeiro et al., 2017). Hauser (2018), using otolith microchemistry, recently provided clear evidence that, although some downstream passage of larvae and juveniles of gilded catfish through fishways, turbines or spillways cannot be excluded, pre-adults migrating upstream cannot pass these structures. The rupture of recruitment of new individuals from downstream would mean that the individuals caught in the upstream Madeira after dam closure are mostly old homers which had passed before dam construction.

In the worst-case scenario, where the fishways would remain ineffective to accommodate the upstream passage and recruitment of new homing sub-adults, the remaining old reproducing homers will gradually disappear from the upper Madeira due to natural and fishing-induced mortality. This population decrease probably contributes to explaining the decreasing CPUE observed during the post-dam period. As the maximum observed age was 15 years in the Madeira River (Hauser et al., 2018) and assuming that the last homers that returned to Bolivia were 3 to 4 years old in 2011 before dam closure (Hauser, 2018; Hauser et al., 2018), they could become extinct in the upper Madeira basin approximately twelve years after Santo Antônio dam closure, hence around 2024.
Microchemistry analysis of otoliths (Hauser, 2018) has shown that since the dam's closure most of the old homers' offspring became "forced residents", being trapped upstream of the dams within the upper Madeira. However, the relative contribution of these fishes to the catch in the Ichilo River is still unclear, due to the difficulty of backcalculating individual age based on weight data. Weights and/or fish lengths are inherently weak predictors of age owing to the sigmoid nature of the weight- or lengthage curve of the species (Hauser et al., 2018). Based on weight data, the gilded catfish captured in the study area in the pre-dam period (1998-2007) might have had any age between 2-3 and 15 years old, their maximum observed age in the Madeira basin (Hauser et al., 2018). Moreover, there is a significant size dimorphism between males and females in B. rousseauxii (García Vásquez et al., 2009; Agudelo Córdoba et al., 2013; Hauser et al., 2018), additionally limiting the possibility of age prediction in the present study, entirely based on unsexed mature individuals. This means that based on weight data alone the relative contribution of old reproducing homers and forced residents to the catch cannot be established. In the post-dam period (2015-2017), most individuals caught had probably returned to the upper Madeira before dam closure, but the smallest fish ( 7 and $8 \mathrm{~kg}$ ) probably are forced residents trapped above the dam, as they would be too young to have migrated back to the upper Madeira before dam closure (see Hauser, 2018).

The forced residents trapped upstream of the dams have a slower growth than homers (Hauser, 2018), which might further impact recruitment as fecundity is proportional to body length and weight (Garcia Vásquez et al., 2009). Alternatively, some of these residents might adapt to this reduced life cycle and hopefully rebuild a sustainable population in time, providing that eggs and larvae can find appropriate habitats, and that fishing and natural mortalities will not outweigh recruitment. However, the strong decline in number of $B$. rousseauxii in the upper Madeira after dam closure suggests that only very few forced residents survive to adulthood. To predict how resident individuals, both natural or forced, will be affected by the dams, key information is still missing on their reproductive capabilities. It will be necessary to analyze otoliths of ripe or just spent individuals using $\mathrm{Sr}$ isotopic analyses, in order to determine whether resident individuals actually do participate in reproduction.

The possible extinction or the strong reduction of $B$. rousseauxii in the Madera basin would have both economic and ecological consequences at a regional scale. In Bolivia, the species contributed to approximately 5\% of annual commercial fisheries landings (Van Damme et al., 2011) and represents an actual economic value of more or less 56 000 US\$ (Navia et al., 2019). Before dam closure (20042008) the gilded catfish commercialized in the Porto Velho fish market, which is the largest in the Brazilian portion of the Madeira basin, represented an economic value of 
approximately 345000 US\$ (Lima, 2017). Because it is an apex predator (Barthem, Goulding, 1997; Barbarino Duque, Winemiller, 2003; Angelini et al., 2006), it is likely that its depletion would generate top-down cascading impacts on food webs (Angelini et al., 2006; Duponchelle et al., 2016; Lima et al., 2020), with additional unpredictable socioeconomic impacts. Also, since forced residents have a lower growth rate than specimens performing the complete migratory life cycle (Hauser, 2018) fishery quality could be affected even if the species could adapt to a shorter life cycle within the upper Madeira River, avoiding the lower Amazon as a growing area. It is also necessary to assess if the Madeira populations could use alternative spawning grounds in other Amazonian rivers. Hauser (2018) found that aproximately $8 \%$ of the Madeira individuals were strayers hatched in the upper Amazon and hence not showing compulsory homing. Further ecosystem and economic modeling would be necessary to evaluate future scenarios at a basin scale.

We recommend that $B$. rousseauxii should by now be considered endangered in the Upper Madeira basin, having fallen to less than $10 \%$ of its base line CPUE, using criteria established by IUCN (2017). The presence of homing at basin-scale may enhance the extinction probability of the upper Madeira basin population and promote the disappearance of a complete genetic line and impoverishment of the overall genetic variability of the species (Carvajal-Vallejos et al., 2014). Mitigation measures will be necessary to avoid the extinction of $B$. rousseauxii in the upper Madeira. As this species performs very long transboundary migratory movements, international management policies along the basin are needed. Also, efficiency at both fishways should be improved to ensure that gilded catfish preadults can pass upstream (Hauser, 2018) as well as to reduce the mortality rate triggered by the reservoir, turbines and spillways on larvae drifting downstream (Molina Carpio, 2011). As several more dams are planned for the basin (Winemiller et al., 2016; Latrubesse et al., 2017; Anderson et al., 2018), impacts on large migratory catfish should be considered at a larger scale than traditional impact studies did (Goulding et al., 2019).

This study documented for the first time how dams affected upstream populations of large catfish in the Amazon basin and impacted on artisanal fisheries sustainability. Although the Madeira case can be considered as a pioneer study case for whitewater rivers in the Amazon, it offers reliable evidence that river fragmentation could have a strong impact on large migratory catfishes, that cannot be mitigated or ameliorated by current fish passage technologies. The observed decline of the gilded catfish is a strong indication that populations of other long-range or mid-range migratory species might respond similarly to the dams. This situation will aggravate if the other planned dams on the Madeira basin or other Amazonian large rivers are to be implemented.

\section{Acknowledgments}

The final version of this manuscript has improved considerably thanks to the valuable input of three anonymous reviewers. The authors acknowledge the support provided by the commercial fishers of Puerto Villarroel, organized in local fisheries organizations ASPECO and ASPIMCO. We thank in particular the subsequent leaders of ASPECO who have organized and supervised monitoring, Javier Lopez, Fortunato Vargas, Adrian Mendoza, Ademar Galarza, Omar Ortuño and Jhonny Severich. Jorge Molina Carpio provided water level data for the Ichilo River, and Blanca Vega prepared the map of the study area. SEDAG-Cochabamba is acknowledged for permissions to monitor fisheries and for providing official fisheries statistics of the department of Cochabamba. The monitoring system was set up with support of the Inter-University Cooperation (VLIR) between the San Simón University (Cochabamba, Bolivia) and the Catholic University of Leuven (Belgium). The monitoring after dam closure was financed by WWF-Bolivia. Financial and technical support to the team to write up this paper was provided by the IDRC (Canada) through a grant to the "Peces para la Vida" project by Global Affairs (DAAGD), Canada, and by WWF-Bolivia. M. Hauser received a scholarship from CAPES (Proc. No 88887.313344/2019-00, PROCAD Amazonia 2018-Linha 1).

\section{References}

Agostinho AA, Pelicice FM, Gomes LC. Dams and the fish fauna of the Neotropical region: Impacts and management related to diversity and fisheries. Braz J Biol. 2008; 68(4, Suppl.):1119-32. http://dx.doi.org/10.1590/S1519-69842008000500019

Agudelo Córdoba E, Joven León AV, Bonilla-Castillo CA, Petrere Jr M, Peláez M, Duponchelle F. Breeding, growth and exploitation of Brachyplatystoma rousseauxii Castelnau, 1855 in the Caqueta River, Colombia. Neotrop Ichthyol. 2013; 11(3):637-47. http://dx.doi.org/10.1590/S167962252013000300017

Anderson EP, Jenkins CN, Heilpern S, Maldonado-Ocampo JA, Carvajal-Vallejos FM, Encalada AC et al. Fragmentation of Andes-to-Amazon connectivity by hydropower dams. Sci Adv. 2018; 4(1):eaao1642. Available from: https://advances. sciencemag.org/content/4/1/eaao1642

Angelini R, Fabré NN, Silva-Jr UL. Trophic analysis and fishing simulation of the biggest Amazonian catfish. Afr J Agric Res. 2006; 1(5):151-58.

Baigún CRM, Nestler JM, Oldani NO, Goodwin RA, Weber LJ. Can north american fish passage tools work for South American migratory fishes. Neotrop Ichthyol. 2007; 5(2):10919. http://dx.doi.org/10.1590/S1679-62252007000200004

Baigún CRM, Nestler JM, Minotti P, Oldani N. Fish passage system in an irrigation dam (Pilcomayo River basin): When engineering designs do not match ecohydraulic criteria. Neotrop Ichthyol. 2012; 10(4):741-50. http://dx.doi. org/10.1590/S1679-62252012000400007 
Barbarino Duque A, Winemiller KO. Dietary segregation among large catfishes of the Apure and Arauca Rivers, Venezuela. J Fish Biol. 2003; 63(2):410-27. https://doi.org/10.1046/ j.1095-8649.2003.00163.x

Barthem RB, Fabré NN. Biologia e diversidades dos recursdos pesqueiros da Amazônia. In: Ruffino M, editor. A pesca e os recursos pesqueiros na Amazônia brasileira. Manaus: Ibama/ ProVárzea; 2004. p.11-55.

Barthem R, Goulding M. The catfish connection: Ecology, migration and conservation of Amazon predators. New York: Columbia University Press; 1997.

Barthem R, Goulding M. An unexpected ecosystem: The Amazon as revealed by fisheries. Lima, Peru: Amazon Conservation Association \& Missouri Botanical Garden Press; 2007.

Barthem RB, Goulding M, Leite RG, Cañas C, Forsberg B, Venticinque E, Petry P, Ribero MLB, Chuctaya J, Mercado A. Goliath catfish spawning in the far western Amazon confirmed by the distribution of mature adults, drifting larvae and migrating juveniles. Sci Rep. 2017; 7:41784. https://doi. org/10.1038/srep41784

Batista VS, Isaac VJ, Fabré NN. A produção desembarcada por espécie e sua variação por macrorregião amazônica. In: Batista VS, editor. Peixes e pesca no Solimões-Amazonas: Uma avaliação integrada. Brasília: Ibama/ProVárzea; 2012. p.107-35.

Carvajal-Vallejos FM, Duponchelle F, Desmarais E, Cerqueira F, Querouil S, Nuñez J, Garcia C, Renno JF. Genetic structure in the Amazon catfish Brachyplatystoma rousseauxii: Influence of life history strategies. Genetica. 2014; 142(4):323-36. https://doi.org/10.1007/s10709-014-9777-2

Castello L, Macedo MN. Large-scale degradation of Amazonian freshwater ecosystems. Global Change Biol. 2016; 22(3):9901007. https://doi.org/10.1111/gcb.13173

Cella-Ribeiro A, Assakawa LF, Torrente-Vilara G, Zuanon J, Leite RG, Doria C, Duponchelle F. Temporal and spatial distribution of young Brachyplatystoma spp. (Siluriformes: Pimelodidae) along the rapids stretch of the Madeira River (Brazil) before the construction of two hydroelectric dams. J Fish Biol. 2015; 86(4):1429-37. https://doi.org/10.1111/ jfb. 12630

Cella-Ribeiro A, Doria CRC, Dutka-Gianelli J, Alves H, TorrenteVilara G. Temporal fish community responses to two cascade run-of-river dams in the Madeira River, Amazon basin. Ecohydrology. 2017; 10(8):e1889. https://doi.org/10.1002/ eco. 1889

Coronel JS, Maes GE, Claus S, Van Damme PA, Volckaert FAM. Differential population history in the migratory catfishes Brachyplatystoma flavicans and Pseudoplatystoma fasciatum (Pimelodidae) from the Bolivian Amazon assessed with nuclear and mitocondrial DNA markers. J Fish Biol. 2004; 65(3):859-68. https://doi.org/10.1111/j.00221112.2004.00498.x

Cruz REA, Isaac VJ, Paes ET. The fishing of gilded catfish Brachyplatystoma rousseauxii (Castelnau, 1855) in the lower Amazon, Brazil. Bol Inst Pesca. 2017; 43(4):474-86. https:// doi.org/10.20950/1678-2305.2017v43n4p474
Doria CRC, Duponchelle F, Lima MAL, Garcia A, CarvajalVallejos FM, Coca Méndez C et al. Review of fisheries resource use and status in the Madeira river basin (Brasil, Bolivia and Peru) before hydroelectric dam completion. Rev Fish Sci Aquac. 2018a; 26(4):494-514. https://doi.org/10.108 0/23308249.2018.1463511

Doria CRC, Lima MAL, Angelini R. Ecosystem indicators of a small-scale fisheries with limited data in Madeira River (Brazil). Bol Inst Pesca. 2018b; 44(3):e317. https://doi. org/10.20950/1678-2305.2018.317

Duponchelle F, Pouilly M, Pécheyran C, Hauser M, Renno $\mathrm{JF}$, Panfili $\mathrm{J}$ et al. Trans-Amazonian natal homing in giant catfish. J Appl Ichthyol. 2016; 53(5):1511-20. https://doi. org/10.1111/1365-2664.12665

Fearnside PM. Impacts of Brazil's Madeira River dams: Unlearned lessons for hydropower development in Amazonia. Environ Sci Policy. 2014; 38:164-72. https://doi.org/10.1016/j. envsci.2013.11.004

Forsberg BR, Melack JM, Dunne T, Barthem RB, Goulding M, Paiva RCD et al. The potential impact of new Andean dams on Amazon fluvial ecosystems. PLoS ONE. 2017; 12(8):e0182254. https://doi.org/10.1371/journal.pone.0182254

García Vásquez A, Alonso JC, Carvajal F, Moreau J, Nuñez $\mathrm{J}$, Renno JF et al. Life-history characteristics of the large Amazonian migratory catfish Brachyplatystoma rousseauxii in the Iquitos region, Peru. J Fish Biol. 2009; 75(10):2527-51. https://doi.org/10.1111/j.1095-8649.2009.02444.x

Godinho AL, Kynard B. Migratory fishes of Brazil: Life history and fish passage needs. River Res Applic. 2009; 25(6):702-12. https://doi.org/10.1002/rra.1180

Goulding M, Venticinque E, Ribeiro MLB, Barthem RB, Leite RG, Forsberg B et al. Ecosystem-based management of Amazon fisheries and wetlands. Fish Fish. 2019; 20(1):138-58. https:// doi.org/10.1111/faf.12328

Hahn L, Martins E, Nunes LD, Machado LS, Kilpp JC, Câmara LF. Avaliação da eficiência do sistema de transposição de peixes da UHE Santo Antônio na passagem de bagres migradores do rio Madeira, Amazônia, com a utilização de telemetria combinada. Anais XXII Encontro Brasileiro de Ictiologia (n 497-1). Porto Seguro, Bahia, Brazil; 2017.

Hauser M. Migração dos grandes bagres amazónicos pela perspectiva dos isótopos de estroncio em otólitos. [PhD Thesis]. Porto Velho; Universidade Federal de Rondônia; 2018. Available from: http://www.ri.unir.br/jspui/bitstream/123456789/2659/1/ Tese_Mari\%CC\%811ia\%20Hauser-4.9MB.pdf

Hauser M, Doria CRC, Melo LRC, Santos AR, Ayala DM, Nogueira LD et al. Age and growth of the Amazonia migratory catfish Brachyplatystoma rousseauxii in the Madeira River basin before the construction of dams. Neotrop Ichthyol. 2018; 16(1):e170130. http://dx.doi.org/10.1590/1982-022420170130

Hauser M, Doria CRC, Santos RV, Garcia-Vasquez A, Pouilly M, Pécheyran $\mathrm{C}$ et al. Shedding light on the migratory patterns of the Amazonian goliath catfish, Brachyplatystoma platynemum, using otolith 87Sr/86Sr analyses. Aquat Conserv. 2019; 29(3):397-408. https://doi.org/10.1002/aqc.3046 
International Union for Conservation of Nature (IUCN). Standards and petitions subcommittee. Guidelines for using the IUCN Red List categories and criteria. Version 13 [Internet]. Gland; 2017. Available from: http://cmsdocs. s3.amazonaws.com/RedListGuidelines.pdf

Latrubesse EM, Arima EY, Dunne T, Park E, Baker VR, d'Horta FM et al. Damming the rivers of the Amazon basin. Nature. 2017; 546(7658):363-69. https://doi.org/10.1038/ nature 22333

Lees AC, Peres CA, Fearnside PM, Schneider M, Zuanon JAS. Hydropower and the future of Amazonia biodiversity. Biodivers Conserv. 2016; 25(3):451-66. https://doi. org/10.1007/s10531-016-1072-3

Lima MAL. História do ecossistema e dos recursos pesqueiros frente a implementação de hidreléctricas na bacia do río Madeira. [PhD Thesis]. Porto Velho: Universidade Federal de Rondônia; 2017. Available from: http://ri.unir.br/jspui/ handle/123456789/2199

Lima MAL, Carvalho AR, Nunes MA, Angelini R, Doria CRC. Declining fisheries and increasing prices: The economic cost of tropical rivers impoundment. Fish Res. 2020; 221:105399. https://doi.org/10.1016/j.fishres.2019.105399

Lima MAL, Kaplan DA, Doria CRC. Hydrological controls of fisheries production in a major Amazonian tributary. Ecohydrology. 2017; 10(8):e1899. https://doi.org/10.1002/ eco.1899

Lira NA, Pompeu PS, Agostinho CS, Agostinho AA, Arcifa MS, Pelicice FM. Fish passages in South America: An overview of studied facilities and research effort. Neotrop Ichthyol. 2017; 15(2):e160139. http://dx.doi.org/10.1590/1982-022420160139

Molina Carpio J. Funcionamiento de componentes de las represas del rio Madera en relación al paso de peces: Vertederos, turbinas y sistemas de trasposición de peces. In: Van Damme PA, Carvajal-Vallejos FM, Molina Carpio J, editors. Los peces y delfines de la Amazonia boliviana: Hábitats, potencialidades y amenazas. Cochabamba, Bolivia: Edit. INIA; 2011. p.417-41.

Montanhini Neto R, Nocko HR, Ostrensky A. Environmental characterization and impacts of fish farming in the cascade reservoirs of the Paranapanema River, Brazil. Aquacult Environ Interact, 2015; 6(3):255-72.

MRE-MMAyA, editor. Sistema de monitoreo de los impactos de las represas hidroeléctricas Jirau y Santo Antonio en territorio boliviano: Línea de base de ecosistemas y recursos acuáticos en la Amazonía boliviana. Cochabamba, Bolivia: Edit. INIA; 2014.
Navarro G, Maldonado M. Geografía ecológica de Bolivia: Vegetación y ambientes acuáticos. Cochabamba, Bolivia: Editorial Centro de Ecologia Simón I; 2002.

Navia J, Rico Lopez G, Villarroel L, Añez M, Van Damme PA. The vulnerability of fisheries resources to aquatic habitat degradation in the Bolivian Amazon. Rev Bol Ecol Conserv Amb. Forthcoming 2019.

Oldani NO, Baigún CRM, Nestler JM, Goodwin RA. Is fish passage technology saving fish resources in the lower La Plata River basin? Neotrop Ichthyol. 2007; 5(2):89-102.

Pelicice FM, Vitule JRS, Lima Jr DP, Orsi ML, Agostinho AA. A serious new threat to Brazilian freshwater ecosystems: The naturalization of nonnative fish by decree. Conserv Lett. 2014; 7(1):55-60. https://doi.org/10.1111/conl.12029

Pompeu PS, Agostinho AA, Pelicice FM. Existing and future challenges: The concept of successful fish passage in South America. River Res Appl. 2012; 28(4):504-12. https://doi. org/10.1002/rra.1557

Santos RE, Pinto-Coelho RM, Fonseca R, Simões NR, Zanchi FB. The decline of fisheries on the Madeira River, Brazil: The high cost of the hydroelectric dams in the Amazon basin. Fish Manag Ecol. 2018; 25(5):380-91. https://doi.org/10.1111/ fme. 12305

Timpe K, Kaplan D. The changing hydrology of a dammed Amazon. Sci Adv. 2017; 3(11):e1700611. Available from: https://advances.sciencemag.org/content/3/11/e1700611. abstract

Van Damme PA, Carvajal-Vallejos FM, Camacho J, Munoz H, Coronel J. Peces migratorios de la Amazonia boliviana. In: Van Damme PA, Carvajal-Vallejos FM, Molina Carpio J, editors. Los peces y delfines de la Amazonia boliviana: Hábitats, potencialidades y amenazas. Cochabamba, Bolivia: Edit. INIA; 2011. p.149-200.

Winemiller KO, McIntyre PB, Castello L, Fluet-Chouinard E, Giarrizzo T, Nam S et al. Balancing hydropower and biodiversity in the Amazon, Congo and Mekong. Science. 2016; 351(6269):128-29. https://science.sciencemag.org/ content $/ 351 / 6269 / 128$

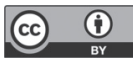

Submitted in January 1, 2019 Accepted in November 8, 2019 by Fernando Pelicice 